\title{
SPECIFICATIONAL COPULAR SENTENCES IN RUSSIAN AND ENGLISH
}

\author{
BARBARA H. PARTEE \\ University of Massachusetts
}

\section{A B S T R ACT}

The Russian sentence (1), from Padučeva \& Uspenskij (1979), and English (2) are examples of specificational copular sentences: $\mathrm{NP}_{2}$ provides the 'specification', or 'value' of the description given by $\mathrm{NP}_{1}$.

$$
\begin{aligned}
& \text { Vladelec ètogo osobnjaka }- \text { juvelir Fužere. } \\
& \text { owner-NOM this-GEN mansion-GEN jeweler-NOM Fuzhere } \\
& \text { 'The owner of this mansion is the jeweler Fuzhere.' }
\end{aligned}
$$

(2) The biggest problem is the recent budget cuts.

Williams (1983) and Partee (1986a) argued that specificational sentences like (2) result from "inversion around the copula": that $\mathrm{NP}_{1}$ is a predicate (type $<e, t>$ ) and $\mathrm{NP}_{2}$ is the subject, a referential expression of type $e$. Partee (1999) argued that such an analysis is right for Russian, citing arguments from Padučeva \& Uspenskij (1979) that $\mathrm{NP}_{2}$ is the subject of sentence (1). But in that paper I argued that differences between Russian and English suggest that in English there is no such inversion, contra Williams (1983) and Partee (1986a): the subject of (2) is $\mathrm{NP}_{1}$, and both NPs are of type $e$, but with $\mathrm{NP}_{1}$ less referential than $\mathrm{NP}_{2}$, perhaps "attributive".

Now, based on classic work by Roger Higgins on English and by Paducheva and Uspensky on Russian, and on a wealth of recent work by Mikkelsen, Geist, Romero, Schlenker, and others, a reexamination of the semantics and structure of specificational copular sentences in Russian and English in a typological perspective supports a partly different set of conclusions: (i) $\mathrm{NP}_{1}$ is of type $<e, t>$ and $\mathrm{NP}_{2}$ is of type $e$ in both English and Russian; (ii) but $\mathrm{NP}_{1}$ is subject in English, while $\mathrm{NP}_{2}$ is subject in Russian; and (iii) $\mathrm{NP}_{1}$ in specificational sentences is universally topical (discourse-old), but only in some languages (like English) is that accomplished by putting $\mathrm{NP}_{1}$ into canonical subject position. In other words, both English (2) and Russian (1) move the $<e, t>$-type $\mathrm{NP}_{1}$ into some sentence-initial position for information-structure reasons, but in English $\mathrm{NP}_{1}$ ends up as syntactic subject, whereas in Russian, it's inverted into some other left-periphery position. 
[1] INTRODUCTION

Compare Russian (1), from Padučeva \& Uspenskij (1979), and English (2).

(1) Vladelec ètogo osobnjaka - juvelir Fužere. Owner-NOM this-GEN mansion-GEN jeweler-NOM Fuzhere 'The owner of this mansion is the jeweler Fuzhere.'

(2) The biggest problem is the recent budget cuts.

The kind of copular sentence exemplified by (1) and (2) has been known as "specificational" since the work of Halliday (1967), Akmajian (1970, 1979), and especially the classic Higgins (1973), which provided insights and examples that have fueled much of the subsequent work on the topic. As Higgins described this kind of copular sentence, the second noun phrase, $\mathrm{NP}_{2}$, provides the 'specification' of the individual described by the first noun phrase, $\mathrm{NP}_{1}$, typically an attributive definite NP. Higgins refers to $\mathrm{NP}_{1}$ as a "Superscriptional NP", functioning very much like the "heading" of a list, a list which may in these sentences have just one item. Williams (1983) and Partee (1986a) argued that in English a specificational sentence like (2) involves "inversion around the copula": $\mathrm{NP}_{1}$ is 'really' a predicate (type $<e, t>$ ) and $\mathrm{NP}_{2}$ is a referential expression (type $e$ ) and is in some sense 'really' the subject.

Partee (1999) compared Russian and English specificational copular sentences like (1) and (2) and reached the following conclusions:

(i) Russian does have inversion around the copula. In this conclusion, Partee (1999) agreed with Paducheva and Uspensky that in sentence (1), $\mathrm{NP}_{2}$ is the subject.

(ii) But in English there is no such inversion, contra Williams (1983) and Partee (1986a): the subject of (2) is $\mathrm{NP}_{1}$. (The number agreement in (2) is one piece of evidence, but not by itself conclusive.)

(iii) Partee (1999) also abandoned the earlier claim that $\mathrm{NP}_{1}$ in an English specificational sentence has predicate type $\left\langle e, t>\right.$, claiming that as a subject, $\mathrm{NP}_{1}$ is of type $e$, although in some sense less referential than $\mathrm{NP}_{2}$, which is uncontroversially e-type.

Partee (1999) concluded (with many open questions) that the Williams-Partee proposals would be correct for Russian but were not correct for English. That paper also suggested information structure as a motivation for the sentence-initial position of $\mathrm{NP}_{1}$ in both languages, an approach also advocated by others before and since.

In the light of newer research by Mikkelsen (2004b) (English and Danish), Geist (2007) (Russian and English), Romero (2005), Schlenker (2003), and others, I now 
defend a view that returns in part to the approach of Williams (1983) and Partee (1986a), while agreeing with Partee (1999) that the subject of a specificational sentence is $\mathrm{NP}_{1}$ in English, $\mathrm{NP}_{2}$ in Russian. The conclusions I argue for in this paper are as follows:

(i) English and Russian do indeed differ at the syntactic level on whether they make $\mathrm{NP}_{1}$ the subject in a specificational sentence.

(ii) In both languages, $\mathrm{NP}_{1}$ has predicate type $<e, t>$ or something similar - possibly a nominalized property in English, of type $e$; or possibly a concealed question. The semantics of specificational sentences ends up the same in both languages.

(iii) $\mathrm{NP}_{1}$ in specificational sentences is universally a topic (discourse-old); but only in some languages does it become syntactic subject.

In Section [2] I review the classification of copular sentences into predicational, equative, and specificational, along with some of the main properties that distinguish specificational sentences from the others. Section [3] discusses the syntax of specificational sentences, including debates about which NP is the subject, with special attention to Mikkelsen (2004a)'s evidence for distinguishing between predicate-fronting operations ${ }^{1}$ that do and do not put the predicate-type expression into subject position. The conclusion of Section [3] is that while $\mathrm{NP}_{1}$ is topic in both English and Russian, it is the subject in English, but is a non-subject in Russian. Section [4] is concerned with the semantics of different kinds of copular sentences, including the issue of the semantic types of $\mathrm{NP}_{1}$ and $\mathrm{NP}_{2}$ in specificational sentences. Drawing especially on arguments of Mikkelsen for English and Geist for Russian, we conclude that $\mathrm{NP}_{1}$ is a property-type expression (or something effectively similar) in both Russian and English. Section [5] addresses the information structure of specificational sentences, and the hypothesis that the form of specificational sentences is motivated by discourse functions. The difference between Russian and English is then a difference in grammaticization: Russian achieves the given discourse function by topicalization of a predicate, while English makes the fronted $\mathrm{NP}_{1}$ the subject in order to indicate its pragmatic topical (discourse-old) status. Section [6] concludes by putting those results in the typological context of other similar differences between English and Slavic, including passivization, "dative movement", and existential sentences, differences that were noted and emphasized by Mathesius $(1961,1975)$ and in subsequent work in Prague School linguistics.

[1] I speak informally of predicate-fronting "operations", but that should not be taken as implying any preference for derivational frameworks over monostratal frameworks, where the corresponding kinds of syntactic relatedness would be expressed without appeal to movement rules. 
[2] KINDS OF COPULAR SENTENCES

Higgins (1973) proposed a fourfold distinction among copular sentences that may all have the surface form " $\mathrm{NP}_{1}$ be $\mathrm{NP}_{2}$ "; subsequent scholars have generally agreed in recognizing at least three of the kinds identified by Higgins, ${ }^{2}$ with various proposals for merging or splitting some of them. The three most widely accepted kinds of copular sentences of the form " $\mathrm{NP}_{1}$ be $\mathrm{NP}_{2}$ " are PREDICATIONAL copular sentences, as in (3); EQUATIVE copular sentences, as in (4), and SPECIFICATIONAL copular sentences, as in (5).

(3) PREDICATIONAL

a. Helen is a teacher.

b. Juvelir Fužere - vladelec ètogo osobnjaka. (Russian) Jeweler-NOM Fuzhere owner-NOM this-GEN mansion-GEN 'The jeweler Fuzhere is the owner of this mansion.' (Padučeva \& Uspenskij 1979)

(4) EQUATIVE

a. That woman over there is Susan. (Mikkelsen 2004b)

b. Ciceron - èto Tullij. (Russian) (Geist 2007)

Cicero-NOM PRT $^{3}$ Tully-NOM

'Cicero is Tully.'

(5) SPECIFICATIONAL

a. The winner is Susan.

b. Vladelec ètogo osobnjaka - juvelir Fužere. (Russian) Owner-NOM this-GEN mansion-GEN jeweler-NOM Fuzhere 'The owner of this mansion is the jeweler Fuzhere.' (Padučeva \& Uspenskij 1979) (=(1))

Below I briefly mention some of the main distinctions among these types of copular sentences; see den Dikken (2005) for an overview of syntactic distinctions among them and approaches to their syntactic analysis and Mikkelsen (To appear) for discussion of their semantic properties and debates over their semantic analysis.

[2] Higgins's fourth type, which I will not discuss in this article, are IDENTIFICATIONAL copular sentences, like That is Rosa and That's the mayor; they are analyzed as a type of specificational sentence in Mikkelsen (2004a) and as a type of intensional predicative sentence whose predicate must describe a sORT in Heller $\&$ Wolter (2008).

[3] The particle èto used in equative constructions in Russian is homophonous with the demonstrative èto 'this'; whether it is a separate lexical item or not is a matter of debate; see, for instance Błaszczak \& Geist (2000a,b); Geist (2007); Junghanns (1997); Kimmelman (2009); Padučeva (1982). 
One distinction between referential and predicative NPs in English is that the question word what and pronominal that and it can range over humans when predicative, but not when referential, where one must use who or an animate pronoun like he or she (Higgins 1973).

(6) a. Who is John? John is the president of the club.

$\mathrm{NP}_{2}$ type $e$ : equative. (Geist 2007)

b. What is John? John is the president of the club.

$\mathrm{NP}_{2}$ type $<e, t>$ : predicational.

c. What cooked this beef stew? \#John. OK: This crockpot.

The who question in (6-a) (together with the fact that one can of course also ask Who is the president of the club? and answer John) helps to show that equative sentences have two type $e$ NPs; this is in fact their main defining characteristic. The contrast between (6-a) and (6-b) stems from the fact that definite NPs can be either referential or predicative, as discussed in Partee (1986b); (6-b) is a predicational sentence with a predicate nominal of type $<e, t>$. (This test doesn't work for Russian, since Russian uses $k$ to 'who' for both $e$-type and $<e, t>$-type NP questions.)

Another distinction between predicational and equative sentences is that only the former correspond to the kind of small clause that can be the complement of consider, as illustrated in (7-a)-(7-b), since the second constituent in such a small clause is preferably of type $<e, t>$ (Partee 1986b). The same constraint blocks specificational small-clauses (7-c).

(7) a. They considered Cicero a great orator.

b. *They considered Cicero Tully. (Rothstein 2001, 245)

c. \#? I consider the best person for this job Diana.

Russian predicative expressions, but not $e$-type expressions, can optionally take Instrumental case in past and future tenses; so the predicational (3-b), but not the equative (4-b), has a past tense version with $\mathrm{NP}_{2}$ in the Instrumental: see (8) vs. (9-a)-(9-b). And the specificational sentence (5-b) has a past tense version (10) with $\mathrm{NP}_{1}$ in the Instrumental case, confirming that $\mathrm{NP}_{1}$ in specificational sentences in Russian is of type $<e, t>$.

(8) Juvelir Fužere byl vladelcem ètogo osobnjaka. (Russian) Jeweler-NOM Fuzhere was owner-INSTR this-GEN mansion-GEN 'The jeweler Fuzhere was the owner of this mansion.'

(9) a. Ciceron - èto byl Tullij. (Russian) (Geist 2007)

Cicero-NOM PRT was Tully-NOM

'Cicero was Tully.' 


\section{b. *Ciceron - èto byl Tulliem. (Russian) \\ Cicero-NOM PRT was Tully-INSTR \\ 'Cicero was Tully.'}
(10) Vladelcem ètogo osobnjaka byl juvelir Fužere.
Owner-INSTR this-GEN mansion-GEN was jeweler-NOM Fuzhere
'The owner of this mansion was the jeweler Fuzhere.'

Russian equative sentences have èto; predicational and specificational sentences do not.

One famous and much-studied property of specificational sentences is their exhibition of connectivity effects (Akmajian 1970; Higgins 1973), occurring most famously in specificational pseudoclefts like (11-a) but not only in those, as observed by Higgins: see (11-b). Neither predicational nor equative sentences display connectivity effects.
a. What John is is proud of himself.
b. The only thing the missile damaged was itself.

Much of the theoretically oriented work since Higgins (1973) has been devoted to trying to better understand the syntactic, semantic, and information-structure properties of these sentence types, and to derive their properties from some general principles. Many philosophers and some linguists have posited multiple verbs be as part of their account (Comorovski 2007; Romero 2005; Schlenker 2003); without going into arguments here, we will side with Chvany (1975); Padučeva \& Uspenskij (1979); Déchaine (1993) and den Dikken (2005) in supposing that since the different sorts of two-NP copular sentences can be characterized in terms of the types of the two NPs, it should not be necessary to posit more than one be. This is of course a contentious issue, and some (Déchaine 1993; den Dikken 1995; Kondrashova 1996; Moro 1997) would advocate no contentful be at all. Here I will not be totally committal, but I will assume that there is a single be in all three types of sentences; for concreteness, I will follow Williams (1983) and Partee (1986a), and posit a single be which takes one argument of type $e$ and one of type $\langle e, t>$, and is interpreted as an identity function on its $<e, t>$ argument; this is also the analysis of Mikkelsen $(2004 a, b)$. I consider this relevantly equivalent to assuming that be is semantically empty, as long as the syntax in both cases somehow requires that one 'argument' be of type $e$ and the other of type $\langle e, t>$. For the equative sentences, one can either follow the suggestion of Partee (1986b) that one of the two NPs type-shifts to predicative type via the IDENT function, or the suggestion of Geist (2007) that the copula itself type-shifts in that case. 
[3] SYNTAX OF SPECIFICATIONAL SENTENCES

Many researchers have proposed that in a specificational sentence, in some sense the predication is "turned around". All agree that in specificational sentences, $\mathrm{NP}_{2}$ is "more referential" than $\mathrm{NP}_{1}$. As noted by researchers starting with Higgins (1973), specificational sentences can usually be 'reversed' with little change of meaning: ${ }^{4}$ see (12). Predicational sentences usually cannot be - either the result is 'bad' (13), or it may change meaning and become specificational, as in (14).
a. The winner is Susan (specificational)
b. Susan is the winner (predicational; possibly ambiguously still speci- ficational)

(13) *A teacher is Susan

(14) 'Melanie' is a popular name $\neq$ A popular name is 'Melanie'

Debates about the syntax of specificational sentences center on two issues:

(i) whether $\mathrm{NP}_{1}$ gets into sentence-initial position as the result of some kind of "fronting" of what would otherwise end up as a predicate nominal, and (ii) whether $\mathrm{NP}_{1}$ actually is the subject of the sentence. The combinations of answers to these questions yield four different positions, three of which can be found in the literature. (No one has argued that $\mathrm{NP}_{1}$ is base-generated in initial position but is a non-subject.)

BASE GENERATION OF NP 1 AS SUBJECT: Some authors have argued against viewing specificational sentences as "turned-around" predicational sentences. Heycock \& Kroch $(2002,1999)$ and Rothstein (2001) are influential proponents of this sort of approach. One potential problem for base generation of a type $<e, t>\mathrm{NP}_{1}$ as subject is that subjects are not normally of type $<e, t>$; but that problem is avoided on these approaches, since they analyze specificational sentences as something similar to equative sentences, with two $e$-type arguments.

PREDICATE TOPICALIZATION: Analyses of English specificational copular sentences on which $\mathrm{NP}_{1}$ gets into sentence-initial position by fronting but does not end up as subject include "predicate topicalization" treatments, such as Heggie (1988a,b). Williams (1983) considered inversion a "late, stylistic" rule. Most subsequent work has assumed that such movement is of a more syntactic nature, while maintaining the implicit premise that a predicational sentence like (12-b) is closer to the "basic" or "canonical" form for what (12-a) and (12-b) have in common. For Russian, versions of predicate topicalization for specificational sentences include Padučeva \& Uspenskij (1979); Partee (1999), and Geist (2007). Mikkelsen (2004b) shows that Danish has predicate topicalization, but that it is not the

[4] It is normally assumed that the "reversal" of a specificational sentence is a predicational sentence, and that seems to always be one possible interpretation; we defer discussion of the possible ambiguity of such sentences until Section [5] on information structure. 
source of Danish specificational copular sentences, as we will see just below. This means that topicalizing a predicate does not automatically yield a specificational sentence; the differences between them will be addressed just below.

PREDICATE FRONTING INTO SUBJECT POSITION: Analyses of English specificational sentences with fronting of $\mathrm{NP}_{1}$ into subject position include Moro (1997) and (Mikkelsen 2004b). (Mikkelsen 2004b) gives strong arguments that in English and Danish, $\mathrm{NP}_{1}$ is in subject position in specificational sentences.

Mikkelsen illustrates "predicate topicalization" vs specification in Danish. Example (15) (Mikkelsen 2004b, 22) is ambiguous; negation, as in (16-a)-(16-b) (Mikkelsen $2004 \mathrm{~b}, 24)$, is one of several tests she provides showing that specificational sentences have a different structure from predicational sentences with topicalized predicate.

(15) Den højeste spiller på holdet er Minna. (Danish) (ambiguous)

The tallest player on team-DEF is Minna

'The tallest player on the team is Minna.' (specificational), or

'Minna is the tallest player on the team.' (predicational with pred. topicalization)

(16) a. Den højeste spiller på holdet er IKKE Minna. (specificational)

The tallest player on team-DEF is not Minna

'The tallest player on the team is not Minna.'

b. Den højeste spiller på holdet er Minna IKкE. (pred. topic.)

The tallest player on team-DEF is Minna not

'Minna is not the tallest player on the team.'

Mikkelsen gives a strong set of further arguments showing differences between the two sentence types related to such phenomena as pronominal forms (nominative vs. accusative), reflexives, negative polarity items, word order, yes-no questions, and embedding. Her conclusions are that Danish has predicate "topicalization" structures, as in (16-b), where $\mathrm{NP}_{1}$ (actually $\mathrm{DP}_{1}$, but I will continue to use $\mathrm{NP}$ terminology) is a focused ${ }^{5}$ predicate in $\mathrm{CP}$ and $\mathrm{NP}_{2}$ is the subject (in Spec-IP). And Danish also has specificational structures, as in (16-a), where $\mathrm{NP}_{1}$ is in fact the subject (occupying Spec-IP), and the post-copula $\mathrm{NP}_{2}$ is inside the verb phrase. Here $\mathrm{NP}_{1}$, the subject, is topic (discourse-old), not focus.

Since I will largely follow Mikkelsen on syntax, I show below her syntactic trees for specificational sentences (16-a) and predicational sentences with predicate topicalization (16-b). These are the surface structures, with traces of move-

[5] Terminology concerning "topicalization" is notoriously problematic, as can be seen by doing a Google search on "so-called topicalization". Mikkelsen argues convincingly that what is commonly referred to as predicate topicalization in Danish is really a focusing construction. On the focusing function of "predicate topicalization" in English and Danish, see (Gundel 1988, 143-50), (Heggie 1988a, 66), and Mikkelsen (2005, 2004b). 
ment ${ }^{6}$ shown; the most deeply embedded traces show where things were in deep structure. I slightly modify the trees given in (Mikkelsen 2004b, 24-26), incorporating a very few things from the further details given in Chapter 9, and using subscripts $e t, e$, and $v$ on what I have otherwise here been calling $\mathrm{NP}_{1}, \mathrm{NP}_{2}$, and the copula, and on their traces. In the underlying structure of both, Mikkelsen assumes, following Heggie (1988a,b), that the copula takes as complement a small clause, in which the small-clause subject $\mathrm{DP}_{e}$ is left-adjoined to the smallclause predicate $\mathrm{DP}_{e t}$. But whereas Heggie argues that specificational sentences ARE predicate topicalization sentences, Mikkelsen's evidence from Danish shows that at least for Danish, those are two separate constructions with different surface structures, as shown below.

For the specificational sentence (16-a), the $<e, t>$-type DP ends up in subject position, in the specifier of IP, cf. Figure $1 .^{7}$

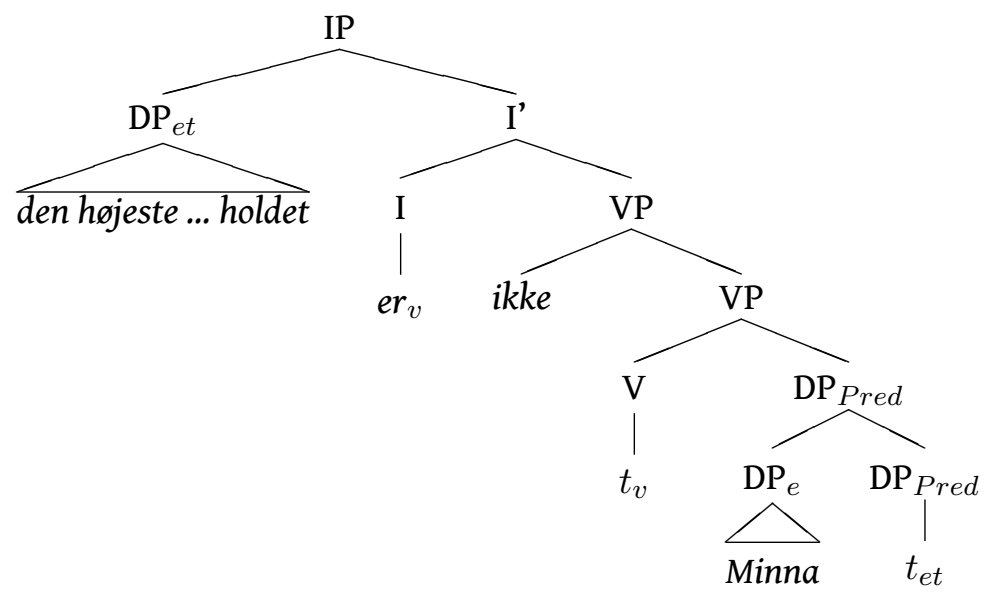

FIGURE 1: Surface structure for the specificational sentence (16-a) (adapted from trees (2.10) and (2.43) in Mikkelsen (2004b)

For the predicational sentence (16-b) with predicate topicalization, on the other hand, her derivation follows Heggie's, and the $<e, t>$-type DP ends up in the specifier of CP. It is the proper name Minna that is in subject position in the specifier of IP, cf. Figure 2 on the next page.

Mikkelsen shows that versions of her arguments are consistent with a range of different theoretical approaches, and with several different proposals about

[6] Like Mikkelsen, I hasten to add that I express the relation between "levels" of syntactic structure in terms of "movement", since so much of syntactic theory has been and still is formulated that way, without thereby intending to imply that movement is the only or the best account of such relations.

[7] "The definite description is in subject position and the proper name inside the verb phrase. The finite verb has moved to I and the negation (ikke) appears between the finite verb and the proper name" (Mikkelsen 2004b, 26). 




FIGURE 2: Surface structure for the predicational sentence (16-b) with predicate topicalization (adapted from trees (2.9) and (2.39) in Mikkelsen (2004b)

the details of specificational sentences. What's clearly established is that making a certain NP initial may or may not involve making it the subject; Danish has both kinds of constructions, and they have different semantic and pragmatic properties as well as different surface syntax. So specificational sentences, in Danish at least, are not formed by predicate "topicalization". $\mathrm{NP}_{1}$ is indeed topic, but it is in syntactic subject position, not in any higher left-periphery position. ${ }^{8}$

As for Russian, Partee (1999) and Geist (2007) show that some of the arguments for subjecthood of $\mathrm{NP}_{1}$ in specificational sentences in English give opposite results in Russian. (i) Number agreement in Russian specificational sentences is with $\mathrm{NP}_{2}$, not $\mathrm{NP}_{1}$. (ii) $\mathrm{NP}_{1}$ may be in the Instrumental case when there is an overt copula (in past and future tenses); that is typical behavior for nominal and adjectival predicates, not otherwise attested for subjects.

We note that Italian also has agreement with $\mathrm{NP}_{2}$ in specificational sentences. Heycock and Kroch argued that Italian specificational sentences are predicational, whereas English specificational sentences are equative. Mikkelsen and Geist both argue against this conclusion: Specificational sentences are not the same as equa-

[8] Mikkelsen notes in a footnote that on some approaches to Danish verb-second phenomena, even the subject would eventually move into a higher left-periphery position like specifier of $\mathrm{CP}$ and I with the verb would move to $\mathrm{C}$; but the primary distinction remains between predicate topicalization of $\mathrm{NP}_{1}$ vs. making $\mathrm{NP}_{1}$ subject. 
tives in any language. Agreement with $\mathrm{NP}_{2}$ may be one strong (but not absolute) argument that predicate topicalization has applied to $\mathrm{NP}_{1}$, and agreement with $\mathrm{NP}_{1}$ is one strong argument that $\mathrm{NP}_{1}$ is subject, but it is important to employ as large a battery of diagnostics as possible for determining which NP is subject in each language. The best evidence so far supports the conclusion that $\mathrm{NP}_{1}$ in Russian specificational sentences is not subject; it is classically agreed to be topic, and could be a 'topicalized predicate' in the Heggie-Mikkelsen sense.

[4] SEMANTICS OF DIFFERENT KINDS OF COPULAR SENTENCES: NP TYPES AND THE COPULA.

While there remain many debates about the semantics of the copula in the various kinds of copular sentences, and about their information structure, there is something close to consensus among semanticists about the semantic types of the NPs, so much so that those are regarded as almost definitional of the sentence types. There is one large caveat concerning details of the semantic type and the semantic and pragmatic analysis of $\mathrm{NP}_{1}$ in specificational sentences, but modulo some specifics there is agreement even there.

PREDICATIONAL SENTENCES: In predicational sentences like (3-a)-(3-b), $\mathrm{NP}_{1}$ is referential, type $e .\left(\mathrm{NP}_{1}\right.$ may also be quantificational, of type $<<e, t>, t>$, but that is true for just about every NP position that is basically of type $e$, so such NPs may be safely ignored here.) $\mathrm{NP}_{2}$ is predicative, type $<e, t>.^{9}$ In predicational sentences, the copula may be regarded as empty, or as an identity mapping on predicates, $\lambda P[P]$, or as in Partee (1986b) as the 'predication relation' $\lambda P \lambda x[P(x)]$. These are all effectively equivalent: the copula in such sentences is just acting as some sort of go-between: what follows it is to be predicated of the subject. When and why a copula is required at all is the subject of a large literature; we ignore that question here.

EQUATIVE SENTENCES: The distinctive semantic characteristic of equative sentences is that $\mathrm{NP}_{1}$ and $\mathrm{NP}_{2}$ are both basically referential, type $e$. On the Williams-Partee approach, one of them shifts to predicate type by the ident relation of Partee (1986b), as in (17).

$$
\text { ident (Tully) }=\lambda x[x=\text { Tully }] \text { (the property of being identical to Tully) }
$$

The copula itself remains the same as in a predicational sentence; it is its demand for one $<e, t>$ argument that coerces the shift of type of one of the NPs. And although it is not fully explicit in Williams (1983) or Partee (1986a), it may be posited

[9] As in Partee (1986b) and much subsequent literature, I systematically ignore the distinction between intensional property-type and extensional predicate-type, representing both for simplicity as $\langle e, t>$. 
that it is the pragmatically rhematic (discourse-new, or informationally focused) $\mathrm{NP}$ that shifts to type $\langle e, t>$, and the topical or discourse-old NP that is chosen to be $\mathrm{NP}_{1}$, in subject position and of type $e$.

On Geist's approach (Geist 2007), the copula instead shifts to express the identity relation on entities: $\lambda y \lambda x[y=x]$.

Geist (2007) uses Russian (and English) to argue against the Partee/Williams account of Identity sentences, on which $\mathrm{NP}_{2}$ shifts from type $e$ to type $<e, t>$, to yield $\lambda x[x=$ Tully $]$. Her main argument is based on the idea that only overt elements can undergo type-shifting. The argument concerns predicative èto: It's required in be-less identity sentences, but not required in past or future sentences, where there is an overt form of the copula.
Cicero-NOM PRT Tully-NOM
'Cicero is Tully.'
a. Ciceron - èto Tullij (Russian) Geist (2007)
b. *Ciceron - Tullij
Cicero-NOM Tully-NOM
'Cicero is Tully.'
c. Ciceron - (èto) byl Tullij
Cicero-NOM PRT was Tully-NOM
'Cicero was Tully.'

Geist argues that null elements cannot type-shift, and that explains why èto is required in present tense copular sentences. It 'substitutes' for the copula (cf. Hebrew as well as various South Slavic languages which also have a 'pronominal' copula in sentences with no overt verbal copula.) She derives a suitable reading for this èto.

If (as Williams and Partee claimed) $\mathrm{NP}_{2}$ could shift to mean $[\lambda x[x=$ Tully $]]$, then according to Geist there should be no need for èto. And there would be no explanation for why English small clauses can't get equative readings as in (19), or (7-b) above:

*Mary considered Cicero Tully.

We leave this interesting debate unresolved; Geist (2007) has indeed shown some problems for the Williams-Partee approach, where one of the e-type NPs shifts to type $\langle e, t>$; her own proposal avoids those problems but posits a shift in the meaning of the copula that does not seem to have independent motivation or to occur anywhere else. Her argument would apply to any one-be or no-be analysis, it would seem. There may be an alternative explanation for the facts Geist has uncovered, but I do not have one. What is not under dispute is that the equative sentences, if they are indeed a separate class, are characterized by having two NPs 
that are both "basically" of type $e$.

SPECIFICATIONAL SENTENCES:

Of the three types of two-NP copular sentences, the semantics of specificational sentences is the most controversial, especially with respect to how to account for connectivity effects. However, I believe there is increasing evidence in both English-like languages and Russian-like languages that $\mathrm{NP}_{2}$ is referential, of type $e$, while $\mathrm{NP}_{1}$ is either property-denoting (type $<e, t>$ ), or of some other related non-canonical subject type: perhaps a concealed question, or a nominalized property, or an intensional attributive expression (Geist 2007; Romero 2005; Schlenker 2003).

Mikkelsen (2004b) shows that Danish gives even clearer evidence than English for such an analysis of specificational sentences; see her work for discussion of the variants of the property-denoting status of $\mathrm{NP}_{1}$ just mentioned. And Geist (2007) provides evidence quite different from Mikkelsen's in favor of something like a property-type analysis of $\mathrm{NP}_{1}$ in Russian specificational sentences.

According to what we might then call the Williams/Partee/Mikkelsen analysis of $\mathrm{NP}_{1}$ in specificational sentences in English (and Danish), $\mathrm{NP}_{1}$ in a specificational sentence is subject, and topic, but it's something like property-denoting. I'll continue to use type $<e, t>$ as a cover term for these proposals (even though, for instance, a nominalized property would be of type $e$, and a concealed question or an attributive intensional expression would have other types). What it's not is a simple referential type $e$ expression. For the purposes of this paper, lumping the variants of the property-type hypothesis together should not affect the main points.

Some of Mikkelsen's best arguments that $\mathrm{NP}_{1}$ is property-denoting involve the choice of pronouns anaphoric to $\mathrm{NP}_{1}$ in specificational vs. predicational sentences. The English facts may seem slightly idiosyncratic, but Danish is quite systematic and clear, and reinforces what we find in English.

In an English predicational sentence, with an ordinary e-type subject, if the subject denotes a human, then an anaphoric pronoun in a tag question must be he or she, not it. But with the same subject in a specificational sentence, the anaphoric pronoun must be it, not he or she. The explanation that seems to fit best is that it is the appropriate anaphoric pronoun for property-denoting NPs.

a. The winner was Norwegian, wasn't she? / *wasn't it?

b. The winner was Susan, wasn't it? / *wasn't she?

Danish has two grammatical genders, 'common' and 'neuter'. An anaphoric pronoun normally agrees in grammatical gender with its antecedent; this is uniformly the case for an $e$-type subject of a predicational sentence, as illustrated by the question-answer pair in (21). But when the same common-gender NP is 
the subject of a specificational question, the pronoun anaphoric to it must be the non-agreeing neuter-gender form, as shown in (22), analogous to English it in (20) above.

a. Q: Hvor stor er den største by $i$ Skotland?

How big is the-COM largest city in Scotland

'How big is the largest city in Scotland?' (predicational)

b. A: Den / * Det er større end København. it-COM / it-NEUT is larger than Copenhagen

'It is larger than Copenhagen.' (Mikkelsen 2004b, 125)

a. Q: Hvilken by er den største (by) i Skotland?

which-COM city is the-COM largest (city) in Scotland

'Which city is the largest (city) in Scotland?' (specificational)

b. A: *Den / Det er vist Glasgow. it-COM / it-NEU is PRT Glasgow. (only neuter pronoun possible)

'I believe it's Glasgow.' (Mikkelsen 2004b, 125)

Geist (2007) gives a different kind of argument for the property-type of $\mathrm{NP}_{1}$ in Russian specificational sentences. She first establishes that specificational sentences are not Equatives, by showing that a specificational sentence like (23) cannot contain èto.

$$
\begin{aligned}
& \text { Ubijca staruxi - (*èto) Raskol'nikov. } \\
& \text { Murderer-NOM old.lady-GEN PRT Raskolnikov-NOM } \\
& \text { 'The murderer of the old lady is Raskolnikov.' }
\end{aligned}
$$

So the NPs are not both type $e$. And in a past-tense sentence, $\mathrm{NP}_{1}$ can be marked either Instrumental (24-a) or Nominative (24-b), a characteristic of property-type NPs and APs in Russian, as described in Section [2] above.

a. Pričinoj avarii *byla / byli

Cause-INSTR.F.SG crash-GEN was-F.SG / was-PL

neispravnye tormoza.

unrepaired-NOM.PL brakes-NOM.PL

'The cause of the crash was the unrepaired brakes.'

b. Edinstvennyj, kto stal na našu storonu, *byl /

Only.one-NOM.M.SG who stood on our side was-M.SG /

byla Varvara.

was-F.SG Barbara-NOM.F.SG 
Russian specificational sentences have semantic and pragmatic properties like those in English and Danish, but as Paducheva and Uspensky observed, it's $\mathrm{NP}_{2}$ and not $\mathrm{NP}_{1}$ that is the subject in Russian: $\mathrm{NP}_{2}$ is always Nominative, and the verb agrees with it, as illustrated in (24-a)-(24-b) above.

\section{[5] INFORMATION STRUCTURE OF SPECIFICATIONAL SENTENCES}

Part of what makes specificational sentences distinctive is their pragmatics. Mikkelsen and others argue that the discourse function of the inversion of the predicative $\mathrm{NP}_{1}$ in specificational sentences is to express that $\mathrm{NP}_{1}$ is "discourse-old" in the sense of Birner (1996); it's a kind of topic-driven movement. She argues that what permits this rather unusual (for English) movement is that be is "the lightest of light verbs": it does not assign accusative case, and nothing prevents movement of the predicative $\mathrm{NP}_{1}$ to subject position. The resulting $\mathrm{NP}_{1}$ will then be both semantically predicative and discourse-old, a relatively unusual combination. This explains the restrictions on possible subjects of specificational sentences, including the impossibility of (25), which was earlier (for instance in Partee (1999)) considered a problem for the Williams-Partee predicate inversion hypothesis about specificational sentences.

$$
\text { *A doctor is John. }
$$

There is no absolute prohibition on indefinite subjects of specificational sentences; their existence was already pointed out by Higgins (1973). Examples include (26-a), from Partee (1999), and (26-b),(26-c) from Mikkelsen (2004a).

(26) a. One friend of mine you could talk to is Diana.

b. A philosopher who seems to share the Kiparskys' intuitions on some factive predicates is Unger (1972), who argues that ... (Delacruz 1976, p.195, fn.8 via Mikkelsen 2004a)

c. Another speaker at the conference was the Times columnist Nicholas Kristof, who got Wilson's permission to mention the Niger trip in a column. ${ }^{10}$

There are also examples of the same thing in Russian. Examples (27-b)-(27-c) are from Padučeva \& Uspenskij (1979).

$$
\begin{aligned}
& \text { a. Odin iz moix soavtorov - Uspenskij. (Paducheva, p.c.) } \\
& \text { One-NOM from my coauthors Uspenskij-NOM } \\
& \text { 'One of my coauthors is Uspenskij.' }
\end{aligned}
$$

[10] Mikkelsen gives the source of this example as Seymour M. Hersh, "The Stovepipe", The New Yorker, Oct. 27, 2003, p.86. 

b. Pod"exavšie
byli Napoleon i dva ad"jutanta.
Approaching.ones-NOM were Napoleon and two adjutants
'The/some approachers were Napoleon and two adjutants.'
c. Učastnik našego koncerta - artist Georg Ots.
Participant-NOM our-GEN concert-GEN singer-NOM Georg Ots
'One participant in our concert is the singer Georg Ots.'

Mikkelsen $(2004 \mathrm{a}, \mathrm{b})$ shows convincingly that the kinds of indefinites permitted as $\mathrm{NP}_{1}$ in a specificational sentence are those that can be good discourse-old topics; the problem with (25) is not that its subject is indefinite, but that it is the kind of indefinite that cannot readily be interpreted as discourse-old.

So let's summarize the similarity and differences between Russian and English specificational sentences. (i) Their information structure is the same: $\mathrm{NP}_{1}$ is topic (discourse-old), "is $\mathrm{NP}_{2}$ " is new information. (ii) Their semantics ends up the same, though possibly by slightly different compositional routes: $\mathrm{NP}_{1}$ expresses a property, $\mathrm{NP}_{2}$ is referential (type $e$ ), and the copula is either empty or expresses the predication relation 'turned around'. That combination of semantics and information structure yields something like "The thing that has property $\mathrm{NP}_{1}$ is $\mathrm{NP}_{2}$." (This summary is oversimplified, not least in omitting connectivity issues.) (iii) It's their syntax that's different. In English (and Danish), $\mathrm{NP}_{1}$ is subject, while in Russian $\mathrm{NP}_{2}$ is subject. In both languages there is informationstructure-motivated movement of $\mathrm{NP}_{1}$, but only in English is it movement into subject position.

The semantics/pragmatics of Danish predicate-topicalized sentences is different from that of Russian (and English and Danish) specificational sentences, since in predicate-topicalized sentences, which actually involve as noted a kind of focus construction, the resulting interpretation is roughly paraphrasable as "The property that $\mathrm{NP}_{2}$ has is $\mathrm{NP}_{1}$ " (Mikkelsen 2004b, 19-22). ${ }^{11}$

In the concluding section we put these results into a typological perspective.

\section{[6] TYPOLOGICAL CONCLUSIONS}

We have seen that specificational copular sentences in English (and Danish) on the one hand and in Russian on the other hand are essentially alike in their semantics and information structure, but differ in their syntax: Russian gets the predicative $\mathrm{NP}_{1}$ into a sentence-initial topic position without making it a subject, whereas English makes the topical (discourse-old) $\mathrm{NP}_{1}$ subject. This difference between Russian and English is not an isolated case. Mathesius argued many decades ago that Czech and Russian can use "word order alone" where English uses such transfor-

[11] Russian probably also has the possibility of predicate-topicalization as found in Danish and many other languages, since focused constituents may also occur sentence-initially with a marked intonation; I have not investigated this issue. 
mations as Passive to get the Topic (or Theme) into sentence-initial position.

The difference between the uses English and Slavic make of Passive structures is one of the best-known examples of this sort. Russian has two different passivelike constructions, used with imperfective and perfective verbs respectively, but neither one is used as much as English passive. The reason seems simply to be that one of the motivations for passive in English is to topicalize the direct object; for English, the most natural way to do that is to make the direct object into the surface subject, since the subject is the default topic. Slavic languages can move the object into a left-periphery topic position with no change in grammatical relations; they are more inclined to use passive only when the subject is to be left unexpressed or strongly demoted.

Active vs. passive and predicational vs. specificational may be regarded as "diathesis choices" in English, closely related but distinct argument structures in which the same verb may appear. The choice of which structure to use in a given sentence involves the "relative importance", in some sense, of one of the arguments. There are various kinds of "importance." We have seen that information structure may be a motivating factor for one or the other choice, and that the same information-structure demands may motivate diathesis shifts in one language, like English, but "mere" word-order shifts in another, like Russian.

Another such case seems to be Dative Shift with give/send verbs, although the details of what motivates the choice of the alternating forms in English are still controversial.

(28) a. Mary threw the ball to John.

b. Mary threw John the ball.

Krifka (1999) argues that the two patterns have different semantics: (28-a), in which the ball is surface direct object, has a "cause-go" semantics, while (28-b), in which John is surface direct object, has a "cause-have" semantics. Bresnan et al. (2007) and Rappaport Hovav \& Levin (2008) argue that it's instead a choice motivated by information structure: the one chosen to be direct object is the one with greater topicality. One might offer a typological argument in favor of Bresnan's and Rappaport Hovav and Levin's hypothesis by appealing to the fact that Russian has no such "dative shift", just a word order difference. In Russian, corresponding sentences like (29-a)-(29-b) have no change in the case marking on the NPs, and correspondingly no change in which argument is considered the direct object. With neutral intonation, the final NP is understood as most rhematic, the one right after the verb as more topical or familiar. (Hence the anarthrous NP pis'mo 'a/the letter' is somewhat more likely to be interpreted as definite in (29-a) than in (29-b).) 
(29)
a. Maša poslala pis'mo Ivanu.
Masha-NOM sent letter-ACC Ivan-DAT
'Masha sent the/a letter to Ivan.'
b. Maša poslala Ivanu pis'mo.
Masha-NOM sent Ivan-DAT letter-ACC
'Masha sent Ivan the/a letter.'

If Bresnan's and Rappaport Hovav and Levin's hypothesis about the difference in the English examples is correct, this is a third example in which English makes a structural syntactic distinction and Russian just uses a word order change to signal a marked Information structure. These are also good examples for showing that what is at issue can be a gradient notion of topicality (cf. the Praguian scale of communicative dynamism (Sgall et al. 1986)) and one that need not involve a dedicated syntactic "topic" position.

In order to dispel the possible impression that all English diathesis alternations are motivated principally by information structure and that Russian has no real diathesis alternation, let me add a different sort of diathesis alternation, one in which English and Russian appear to be quite similar, at least with some verbs: the "spray/load" alternations.

In spray/load alternations in English, it is well known that one chooses as Direct Object the more "totally affected" argument Levin (1993).
a. The farmer loaded the wagon with the hay.
b. The farmer loaded the hay onto the wagon.

Russian is similar in this respect, with alternations between accusative marking on the "affected" argument and instrumental case for the substance (the hay in $(30-a))$, or a directional phrase ${ }^{12}$ for the goal argument (the wagon in (30-b): see (31-a)-(31-b).
a. Ivan zagruzil telegu senom.
Ivan loaded-Pf wagon-ACC hay-INST
'Ivan loaded the wagon with hay.'
b. Ivan zagruzil $\mathrm{v}$ telegu seno.
Ivan loaded-Pf in wagon-ACC hay-ACC
'Ivan loaded (the) hay onto the wagon.'

Russian often chooses differently prefixed verbs for the two constructions, so it's not always simply a diathesis choice in Russian, but insofar as it is, it seems to be motivated by the same 'affected argument' property as in English.

[12] Directional prepositions in Russian take accusative objects; the ACC on telegu in (29-b) is licensed by the preposition, whereas in (29-a) ACC marks telegu as direct object of the verb. 
A particularly interesting and controversial example that might be considered a diathesis alternation is the distinction between existential and locative (predicational) sentences in Russian vs. English. In English, there is no doubt that (32-a)-(32-b) are syntactically distinct structures.

a. The/a doctor is (not) in Amherst.

b. There is (not) a doctor in Amherst.

But there is considerable more controversy about the nearest equivalents in Russian.
a. Vrač
byl
$\mathrm{v}$ gorode.
Doctor-NOM.M.SG was-M.SG in town
'The/a doctor was in town.'
b. V gorode byl vrač.
In town was-M.SG doctor-NOM.M.SG
'There was a doctor in town.'
Doctor-NOM.M.SG NEG was-M.SG in town
'The doctor was not in town.'
c. Vrač ne byl $\mathrm{v}$ gorode.
d. Vrača ne bylo $v$ gorode
Doctor-GEN.M.SG NEG was-NEUT.SG in town
'There wasn't a doctor in town.'
e. V gorode ne bylo vrača.
In town NEG was-NEUT.SG doctor- GEN.M.SG
'There wasn't a doctor in town.'

This is a much more complex case; Babby (1980) argued (controversially) that the main difference between existential and locative sentences is a difference in Theme-Rheme structure, reflected in preferred word order (if both are pronounced with neutral intonation) and that in Russian affirmative sentences that was the only difference between them. In Russian negative existential sentences there is a further difference: the NP is marked with the genitive case (the famous Russian Genitive of Negation) and the verb takes a non-agreeing neuter singular form; Babby argued that these alternations reflect the marked themerheme structure of existential sentences. Borschev and Partee have argued in several papers that the diathesis alternation in these Russian examples reflects not theme-rheme structure but another difference they call "Perspectival structure" (Borschev \& Partee 2002a,b; Partee \& Borschev 2004, see also Hazout 2004) for related discussion of Hebrew existential sentences.) However, we conjecture that it would be quite possible for there to be a language very similar to Russian in 
which the difference between existential and locative sentences really did reduce to greater topicality of the "entity" argument vs. the "location" constituent, since it's clear from other constructions that what one language does with a change of argument structure another may be able to do with information-structure-related movement that doesn't change grammatical relations.

The conclusion, then, is that one language may have an information-structuremotivated diathesis choice where another language uses information structure alone, as we see in the difference between English and Russian specificational copular sentences. This paper has offered a small contribution to the cross-linguistic and typological study of interactions among syntax, semantics, and information structure. It is to be hoped that with more work of this kind, it may be possible to partially predict which languages will express certain contrasts in which way from knowing what mechanisms each language has available for expressing information structure.

\section{ACKNOWLEDGMENTS}

I am grateful for discussions with Line Mikkelsen, Liudmila Geist, Maribel Romero, Tony Kroch, Caroline Heycock, and Elena Paducheva in the period between Partee (1999) and this paper, to the participants in Maribel Romero's conference on specificational sentences at the University of Pennsylvania in 2001, and to the audience at the Oslo conference 'Russian in Contrast' at which this paper was presented for comments and suggestions. I am also grateful to an anonymous referee for useful comments on the first draft, and to Line Mikkelsen for helping me then figure out how to interpret and respond to the referee's request for more explicitness about the syntax. All remaining deficiencies are certainly my own.

\section{REFERENCES}

Akmajian, Adrian. 1970. Aspects of the Grammar of Focus in English. Department of Foreign Literatures and Linguistics MIT: Ph. D. dissertation. http://hdl. handle.net/1721.1/15655.

Akmajian, Adrian. 1979. Aspects of the Grammar of Focus in English Outstanding Dissertations in Linguistics. New York: Garland.

Babby, Leonard H. 1980. Existential Sentences and Negation in Russian. Michigan: Karoma Publishers.

Błaszczak, Joanna \& Ljudmila Geist. 2000a. Kopulasätze mit den pronominalen Elementen to/ éto im Polnischen und Russischen. In E. Lang (ed.), Copular and AUX - Constructions, vol. 16 ZAS Papers in Linguistics, 115-139. Berlin: ZAS.

Błaszczak, Joanna \& Ljudmila Geist. 2000b. Zur Rolle des Pronomens to/ éto in 
spezifizierenden Kopula- Konstruktionen im Polnischen und Russischen. In G. Zybatow (ed.), Current Issues in Formal Slavic Linguistics. Linguistik International, vol. 5, 247-257. Frankfurt/Main: Peter Lang.

Borschev, Vladimir \& Barbara H. Partee. 2002a. The Russian genitive of negation in existential sentences: the role of Theme-Rheme structure reconsidered. In E. Hajičová, P. Sgall, J. Hana \& T. Hoskovec (eds.), Travaux du Cercle Linguistique de Prague (nouvelle série), vol. 4, 185-250. Amsterdam: John Benjamins. http: //people.umass.edu/partee/docs/GenNegTravaux.pdf.

Borschev, Vladimir \& Barbara H. Partee. 2002b. The Russian genitive of negation: Theme-rheme structure or perspective structure? Journal of Slavic Linguistics 10. 105-144.

Bresnan, Joan, Anna Cueni, Tatiana Nikitina \& Harald Baayen. 2007. Predicting the Dative Alternation. In I. Kraemer G. Bouma \& J. Zwarts (eds.), Proceedings of the Royal Netherlands Academy of Science Workshop on Foundations of Interpretation, 69-94. Amsterdam: Royal Netherlands Academy of Science. http: //www. stanford.edu/ bresnan/CFI04.pdf.

Chvany, Catherine V. 1975. On the Syntax of BE-Sentences in Russian. Cambridge, MA: Slavica.

Comorovski, Ileana. 2007. Constituent questions and the copula of specification. In I. Comorovski \& K. von Heusinger (eds.), Existence: Semantics and Syntax, 49-77. Dordrecht: Springer.

Déchaine, Rose-Marie A. 1993. Predicates Across Categories: Towards a CategoryNeutral Syntax. University of Massachusetts: Ph. D. dissertation.

Delacruz, Enrique. 1976. Factives and proposition level constructions in Montague grammar. In B.H. Partee (ed.), Montague Grammar, 177-199. New York: Academic Press.

den Dikken, Marcel. 1995. Copulas. Amsterdam Vrije Universiteit Amsterdam/HIL MA thesis.

den Dikken, Marcel. 2005. Specificational copular sentences and pseudoclefts. In M. Everaert \& H. van Riemsdijk (eds.), The Blackwell Companion to Syntax, vol. IV, chap. 61. Oxford: Blackwell. http://web.gc. cuny. edu/dept/lingu/ dendikken/docs/pseudocl.001.pdf.

Geist, Ljudmila. 2007. Predication and equation in copular sentences: Russian vs. English. In I. Comorovski \& K. von Heusinger (eds.), Existence: Semantics and Syntax, 79-105. Dordrecht: Springer. 
Gundel, Jeanette. 1988. The Role of Topic and Comment in Linguistic Theory. New York: Garland.

Halliday, M. A. K. 1967. Notes on transitivity and theme in English. part 2. Journal of Linguistics 3. 199-244.

Hazout, Ilan. 2004. The syntax of existential constructions. Linguistic Inquiry 35. 393-430.

Heggie, Lorie. 1988a. The Syntax of Copular Structures. University of Southern California: Ph. D. dissertation: dissertation.

Heggie, Lorie. 1988b. A unified approach to copular sentences. In H. Borer (ed.), Proceedings of WCCFL, vol. 7, 129-142. Stanford, CA.: Stanford Linguistics Association.

Heller, Daphna \& Lynsey Kay Wolter. 2008. That is Rosa: Identificational sentences as intensional predication. In A. Grønn (ed.), Proceedings of Sinn und Bedeutung, vol. 12, 226-240. Department of Literature, Area Studies and European Languages, University of Oslo. http://www.hf.uio.no/ilos/forskning/ konferanser/SuB12/proceedings/heller_wolter_226-240.pdf.

Heycock, Caroline \& Anthony Kroch. 1999. Pseudocleft connectivity: Implications for the LF interface level. Linguistic Inquiry 30. 327-364.

Heycock, Caroline \& Anthony Kroch. 2002. Topic, focus, and syntactic representations. In L. Mikkelsen \& C. Potts (eds.), Proceedings of WCCFL, vol. 21, 101-125. Somerville, MA: Cascadilla Press.

Higgins, F. R. 1973. The Pseudo-Cleft Construction in English. MIT: Ph. D. dissertation.

Junghanns, Uwe. 1997. On the so-called èto-cleft construction. In M. Lindseth \& S. Franks (eds.), Annual Workshop on Formal Approaches to Slavic Linguistics: The Indiana Meeting (FASL), vol. 6, 166-190. Ann Arbor, MI: Michigan Slavic Publications. http://www.uni-leipzig.de/ jungslav/uj9.html.

Kimmelman, Vadim. 2009. On the interpretation of èto in so-called èto-clefts. In U. Junghanns G. Zybatow, D. Lenertová \& P. Biskup (eds.), Studies in Formal Slavic Phonology, Morphology, Syntax, Semantics and Information Structure: Proceedings of FDSL, vol. 7, 319-329. Frankfurt: Peter Lang.

Kondrashova, Natalia. 1996. The Syntax of Existential Quantification. University of Wisconsin, Ph. D. dissertation. 
Krifka, Manfred. 1999. Manner in dative alternation. In Proceedings of the Eighteenth West Coast Conference on Formal Linguistics (WCCFL), vol. 18, 1-14. Somerville/Medford, MA: Cascadilla Press.

Levin, Beth. 1993. English verb classes and alternations: A preliminary investigation. Chicago: University of Chicago Press.

Mathesius, Vilém. 1961. Obsahový rozbor současné angličtiny na zakladě obecně lingvistickém. Praha: Nakl. Československé akademie věd.

Mathesius, Vilem. 1975. A functional analysis of present day English on a general linguistic basis (edited by J. Vachek). Janua linguarum. Series practica. 208.

Mikkelsen, Line. 2004a. Specificational subjects - a formal characterization and some consequences. Acta Linguistica Hafniensia 36. 79-112. http:// semanticsarchive.net/Archive/zcyOTQxZ/mikkelsen_ACTA04.pdf.

Mikkelsen, Line. 2004b. Specifying Who: On the Structure, Meaning, and Use of Specificational Copular Clauses. University of California, Santa Cruz: Ph. D. dissertation. http://linguistics.berkeley.edu/ mikkelsen/papers/ mikkelsen\%_dissertation.pdf.

Mikkelsen, Line. 2005. Copular clauses: Specification, predication and equation. John Benjamins Publishing Company.

Mikkelsen, Line. To appear. Copular clauses. In C. Maienborn, K. von Heusinger \& P. Portner (eds.), Semantics: An International Handbook of Natural Language Meaning, Berlin: Mouton de Gruyter. http://linguistics.berkeley.edu/ $\sim$ mikkelsen/papers/mikkelsen\%_copular_clauses_web.pdf.

Moro, Andrea. 1997. The Raising of Predicates: Predicative Noun Phrases and the Theory of Clause Structure, vol. 80 Cambridge studies in linguistics. Cambridge, New York: Cambridge University Press.

Padučeva, E. V. 1982. Značenie i sintaksisčeskie funkcii slova èto [Meaning and syntactic functions of the word èto]. In V.P. Grigor'ev (ed.), Problemy strukturnoj linvistiki, 76-91. Moskva: Nauka.

Padučeva, E. V. \& V. A. Uspenskij. 1979. Podležaščee ili skazuemoe? (Semantičeskij kriterij različenija podležaščego i skazyemogo v binominativnyx predloženijax). Izvestija Akademii Nauk SSSR, Serija Literatury i Jazyka 38. 349-360. Reprinted in Uspensky, V.A. 2002, Trudy po nematimatike. Moscow: OGI.

Partee, Barbara. 1986a. Ambiguous pseudoclefts with unambiguous be. In S. Berman, J.-W. Choe \& J. McDonough (eds.), Proceedings of NELS, vol. 16, 
354-366. Amherst, MA: University of Massachusetts. https://udrive.oit. umass.edu/partee/Partee86_AmbigPseudo.pdf. Reprinted in Partee, Barbara H. 2004. Compositionality in Formal Semantics: Selected Papers by Barbara H. Partee. Oxford: Blackwell Publishing, 190-202.

Partee, Barbara H. 1986b. Noun phrase interpretation and type-shifting principles. In J. Groenendijk, D. de Jongh \& M. Stokhof (eds.), Studies in Discourse Representation Theory and the Theory of Generalized Quantifiers, 115-143. Dordrecht: Foris. https://udrive.oit.umass.edu/partee/Partee86_NPInterp.pdf. Reprinted in Partee, Barbara H. 2004, 203-230.

Partee, Barbara H. 1999. Copula inversion puzzles in English and Russian. In K. Dziwirek, H. Coats \& C. M. Vakareliyska (eds.), Annual Workshop on Formal Approaches to Slavic Linguistics: the Seattle Meeting, vol. 7, 361-395. Ann Arbor: Michigan Slavic Publications. http://people.umass.edu/partee/docs/ FASLBEf inalPartee.pdf. Also in UMOP 23: Issues in Semantics and its Interface, ed. K. Kusumoto and E. Villalta, 198-208. Amherst: GLSA (2000).

Partee, Barbara H. \& Vladimir Borschev. 2004. The semantics of Russian Genitive of Negation: The nature and role of Perspectival Structure. In K. Watanabe \& R. B. Young (eds.), Proceedings of Semantics and Linguistic Theory (SALT), vol. 14, 212-234. Ithaca, NY: CLC Publications. http://people.umass .edu/partee/ docs/SALT14ParteeBorschev.pdf.

Rappaport Hovav, Malka \& Beth Levin. 2008. The English dative alternation: The case for verb sensitivity. Journal of Linguistics 44. 129-167. http://www . stanford.edu/ bclevin/mrhbl08dat.pdf.

Romero, Maribel. 2005. Concealed questions and specificational subjects. Linguistics and Philosophy 28. 687-737.

Rothstein, Susan Deborah. 2001. Predicates and their subjects, vol. 74 Studies in linguistics and philosophy. Dordrecht, Boston: Kluwer.

Schlenker, Philippe. 2003. Clausal equations (a note on the connectivity problem). Natural Language \& Linguistic Theory 21. 157-214.

Sgall, Petr, Eva Hajičová \& Jarmila Panevová. 1986. The Meaning of the Sentence in Its Semantic and Pragmatic Aspects. Dordrecht/Prague: Reidel/Academia.

Williams, Edwin. 1983. Semantic vs. syntactic categories. Linguistics and Philosophy 6. 423-446. 
AUTHOR CONTACT INFORMATION

Barbara H. Partee

University of Massachusetts, Amherst

Department of Linguistics

150 Hicks Way

Amherst, MA 01003-9274

USA

partee@linguist.umass.edu 